\title{
Assessing the Involvement of Industries in Global Value Chains
}

\author{
Viktoriia Khaustova $^{1}$, Olena Reshetnyak ${ }^{1 *}$, Mykyta Khaustov $^{1}$, Taras Danko ${ }^{2}$, and Natalia \\ Danko $^{3}$ \\ ${ }^{1}$ National Academy of Sciences of Ukraine, Research Centre of Industrial Problems of Development, \\ 1a Inzhenernyi Ln., Kharkiv, 61166, Ukraine \\ ${ }^{2}$ National Technical University «Kharkiv Polytechnic Institute», 2 Kyrpychova str., 61002, Kharkiv, \\ Ukraine \\ ${ }^{3}$ V. N. Karazin Kharkiv National University, 4 Svobody Sq., Kharkiv, 61022, Ukrainian
}

\begin{abstract}
The purpose of the article is to assess the involvement of industries in global value chains and determine the prospects for intensification of these processes. The research methods are statistical analysis, comparison, graphical analysis. The role of export volumes of high value-added products, their enclosing in global value chains is determined. A methodical approach to assessing the involvement of industries in global value chains is proposed, allowing to detect the state of the country's involvement in the international distribution of labour in concordance with specific industries. The analysis of the structure of exports of industries on the example of Ukraine is carried out, the industries that have a significant export share both in the total exports and in the structure of production output are determined. The leading indicators of the country's involvement in global value chains are computed, as follows: the national added value in the country's exports by industries, the contribution of specific industry sectors of the economy to the national added value of gross exports, the share of the national added value in exports of industries in the total national added value of gross exports. The positioning of industries within the coordinate system «share in the export structure - share of the national added value in exports» is carried out. It is determined that the share of national added value in exports of extractive industries of Ukraine is higher compared to the average of the world countries in this research. At the same time, being lower in the industries of the manufacturing industry, thus justifying the virtual absence of knowledge-intensive and innovative stages of production of the manufacturing industry, which necessitates a deeper specialization in the exports of low-grade products. The directions of a rational integration of the Ukrainian economy into global value chains are substantiated. The measures to be assumed on the part of the government policy to intensify the involvement of Ukrainian producers in global value chains are proposed. Keywords: national value-added in exports, value chain, industry
\end{abstract}

* Corresponding author: olena.reshetnyak@karazin.ua 


\section{Introduction}

Under the current conditions, in the profound development of globalization processes, the role of foreign trade increases due to the consideration of the national economy as not a separate economic system but a system complex of interrelations of economic entities in the worldwide market [1]. The latest trends in the development of world trade are characterized by the increasing influence of internationalization and fragmentation of production on the growth of interdependence of countries within global value chains [2]. This causes the long-term socio-economic development of the country to be conditional on the integration of the country's industries into the global economy, the volumes of exports of products with high added value, and their enclosure in global value chains. So, the country's winnings from foreign trade are determined by its involvement in the vertical specialization of the worldwide market and ensuring the creation of added value. The low level of the national added value in exports of specific industries characterizes the high level of dependence of the industry on import supplies. Despite the growing demand from economists and practitioners, an assessment of the value-added in exports cannot be implemented within the framework of traditional statistics of foreign economic activity, which records gross export and import flows in both the cost and the physical volumes between the national economies. The demand for statistical information concerning international trade-in valueadded caused the creation in 2013 of an appropriate database (TiVA) by the Organization for Economic Cooperation and Development (OECD) in cooperation with the World Trade Organization (WTO). The TiVA database contains 46 indicators for 64 countries (Ukraine is omitted therein) and for 34 sectors of industry and services.

The use of value-added trade information allows to increase the degree of substantiation of the country's economic policy: to increase the accuracy in the assessment of the openness of the economy, the impact of the national currency on the foreign trade flows, to determine the sources of growth of competitiveness of the national products in foreign markets.

The relevance of the problematics of value-added trade assessment is justified in the works of many authors. In one of the first researches devoted to the issues of value-added trade, i. e., the study by D. Hummels, J. Ishii, and K. Yi [3], the authors substantiated the need to determine the foreign component in exports. The approach suggested in that study was further developed in R. Coopman and Z. Wang [4], R. Jonson [5], X. Chen [6], which, in turn, based on Leontiev's matrix of «costs-output», had proposed their methods of studying the national added value in exports, including the value created in different sectors of the economy. A unique UNCTAD study [7], published in 2013, identified the relationship between enclosing in value chains and the economic development of countries worldwide. The assessment of the national value-added impact in exports on the economic development of the world countries was analyzed in the publications by M. Kyzym [8, 9], I. Gryshova [9, 10], the countries not included in the TiVA database (e. g., Belarus) were considered in the works by V. Krivorotov [11], A. Bykov [12, 13], I. Tochitskaya [14], and others. However, because of the results of literary sources analysis, most of the indicators offered by the TiVA database do not concern the economy of Ukraine; hence an assessment of enclosing the individual industries of Ukraine in global value chains along with the determination of the state of involvement of the country in the international division of labour appears to be relevant.

\section{Materials and Methods}

The article aims to assess the involvement of Ukrainian industries in global value chains and determine the prospects for intensification of these processes. 
The object of research is the assessment of the involvement of Ukrainian industries in global value chains.

The methodical approach to assessing the involvement of Ukrainian industries in global value chains includes the following stages:

1. Analysis of the structure of exports of Ukrainian industries and determination of industries that have a significant share of exports in total exports and production output structure.

2. Assessment of the share of national added value in exports by industries of Ukraine. Based on the OECD value-added trading indicators (TiVA) [15], the authors compute the leading indicators of the country's involvement in global value chains (the study does not identify individual partner countries but analyzes the aggregate exports by the industry sectors or agriculture):

- the national added value in the country's exports by industry and industry sector, which characterizes the added value created by the export industry sector in the production process, as well as any added value received from the domestic suppliers and embodied in the exports:

$$
E X G R_{-} D V A_{i}=V * B * E X G R_{i}
$$

where $\mathbf{V}$ - vector of dimension $\mathbf{K} \times 1$, where each element is equal to the specific weight of the gross added value of the industries of the country;

B - global matrix of complete material costs corresponding to the country without taking into account the costs of imports: $B=(I-A)^{-1}, \mathbf{A}-$ global matrix of direct material costs;

$E X G R_{i}$ - gross export of the $i$-th vector of dimension $\mathbf{K} \times 1$, in which all elements are zero, except that corresponds to the $i$-th industry;

- contribution of the $i$-th industry to the national added value of gross exports. The indicator reflects the share in the total value of gross exports of the national added value of exports of the $i$-th industry:

$$
E X G R_{-} D V A S H_{i}=\frac{E X G R_{-} D V A_{i}}{E X G R_{i}} \times 100
$$

- share of the national added value of exports of the $i$-th industry in the total national added value of gross exports:

$$
E X G R_{-} T D V I N D_{i}=\frac{E X G R_{-} D V A_{i}}{\sum_{i}^{N} E X G R_{-} D V A_{i}} \times 100
$$

3. Positioning industries in the matrix's quadrants in the system of coordinates «share in the export structure - share of the national added value in exports». As a result, industries with a share in the export structure and a share of the national added value in exports above the average level in the country's economy are determined. For these industries, the share of national added value in exports is compared with other world countries.

4. Substantiation of a rational integration of Ukraine's economy into global value chains.

\section{Results}

Following the proposed methodical approach on the grounds of the analysis of data of the matrix of «costs-output» of Ukraine based on the data of 2018, the rating of industries is carried out (for comparison, in the analysis are included the agricultural, fisheries and 
forestry industry sectors) by the indicator of the industry share in the export structure as presented by the Fig. 1 .

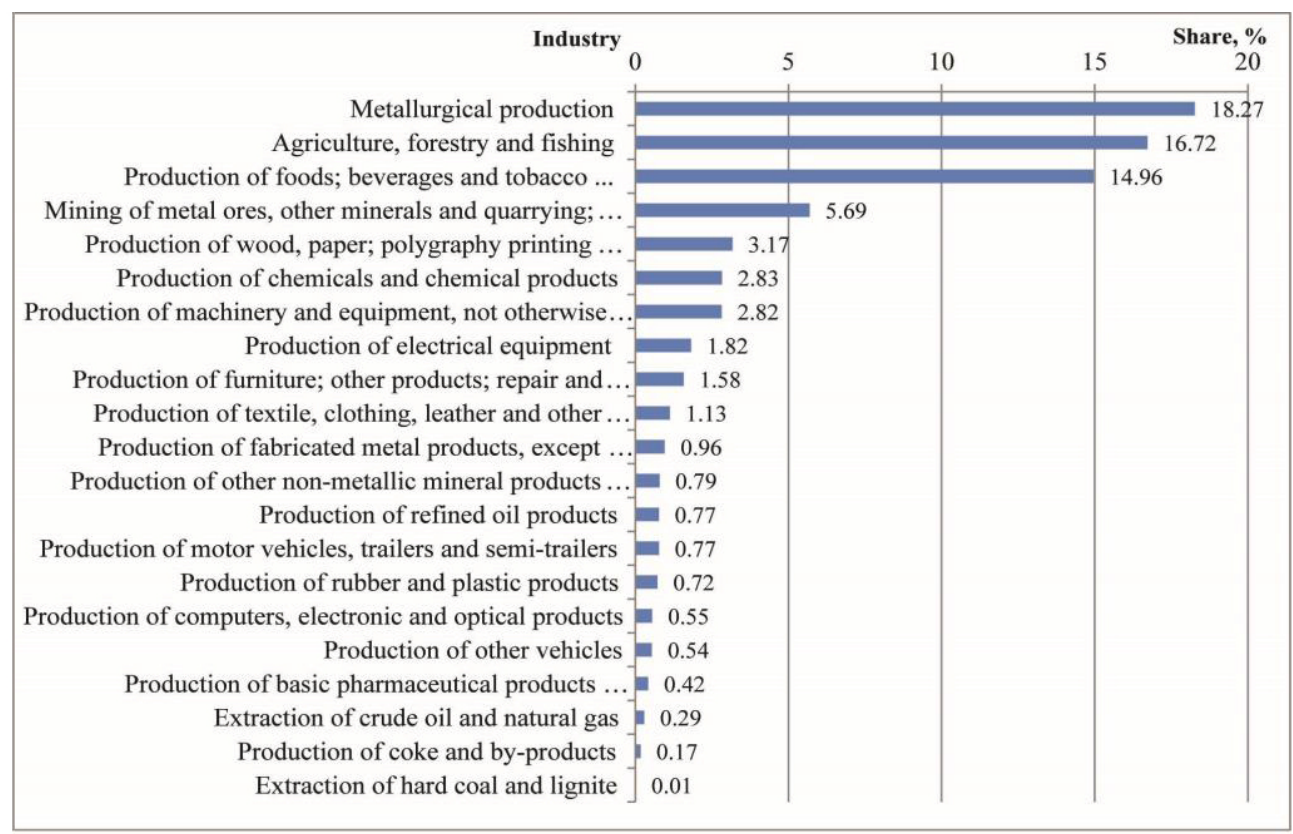

Fig. 1. The rating of industries by share in the export structure according to the year 2018 Source: computed by the authors based on the data [16].

According to the rating, the largest share in the structure of exports of Ukraine's industry in 2018 is held by metallurgical production $(18.27 \%)$, in the second place are agriculture, forestry and fisheries $(16.72 \%)$, in the third-place - production of food and beverages $(14.96 \%)$. It should be noted that high-tech industries - production of computers, electronic and optical products, and essential pharmaceutical products and pharmaceutical preparations have a small share in the export structure (respectively, $0.55 \%$ and $0.45 \%$ ).

The study of the share of exports in the production of the individual industry sectors, agriculture, forestry and fisheries has shown that the most significant share is held by the exports in metallurgical production $(63.57 \%)$, the production of electrical equipment holds the second place $(60.45 \%)$, the production of machinery and equipment - the third place $(59.65 \%)$, according to the data of the year 2018 . The rating of industry sectors, agriculture, forestry and fisheries is presented in Fig. 2.

Also, the indicator of the share of national added value in exports of individual industries, agriculture, forestry and fisheries is computed, characterizing the contribution of specific sectors of the economy to global value chains. The rating of industries by this indicator is presented in Fig. 3. 


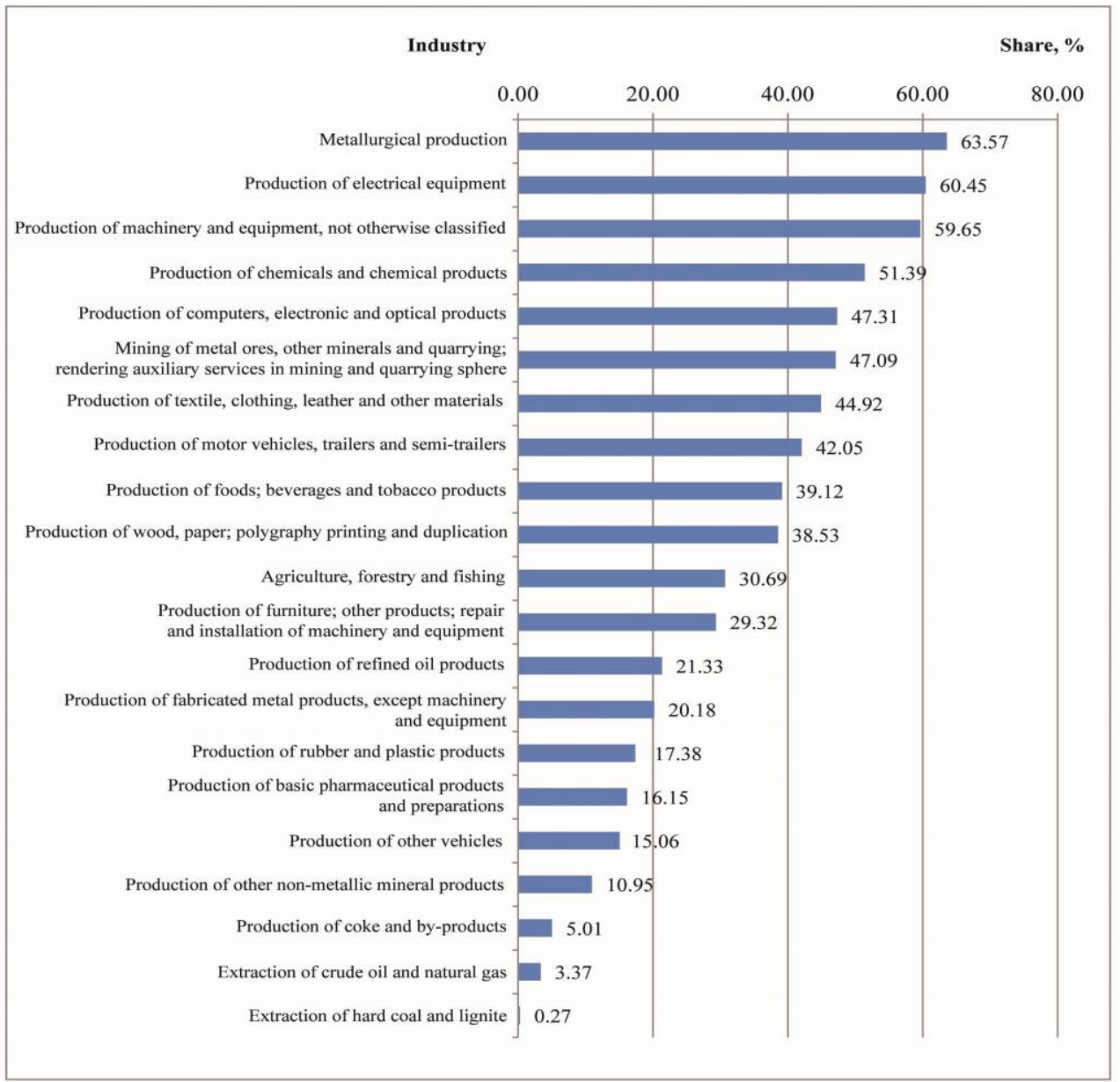

Fig. 2. The rating of individual industries in terms of export share in the production output of individual industries Source: computed by the authors based on the data [16].

Thus, the share of national added value in exports above average $(62.21 \%)$ is shown by the following industries: extraction of hard coal and lignite $(85.57 \%)$, extraction of crude oil and natural gas $(82.91 \%)$, production of other non-metallic mineral products $(79.46 \%)$, production of foods; beverages and tobacco products (76.99), metallurgical production (76.77\%), mining of metal ores, other minerals and quarrying; rendering auxiliary services in mining and quarrying sphere (75.54\%), agriculture, forestry and fishing $(71.01 \%)$, production of fabricated metal products, except machinery and equipment $(70.26 \%)$, production of wood, paper; polygraphy printing and duplication $(65.59 \%)$, production of essential pharmaceutical products and preparations $(65.53 \%)$, production of furniture; production of other products; repair and installation of machinery and equipment $(64.62 \%)$ and production of other vehicles (63.84\%). Other industries have a high level of dependence on import supplies, which exceeds the average level of the total national added value in exports by individual industries of Ukraine. Other industries have a high level of dependence on import supplies, which exceeds the average level of the total national added value in exports by individual industries of Ukraine. 


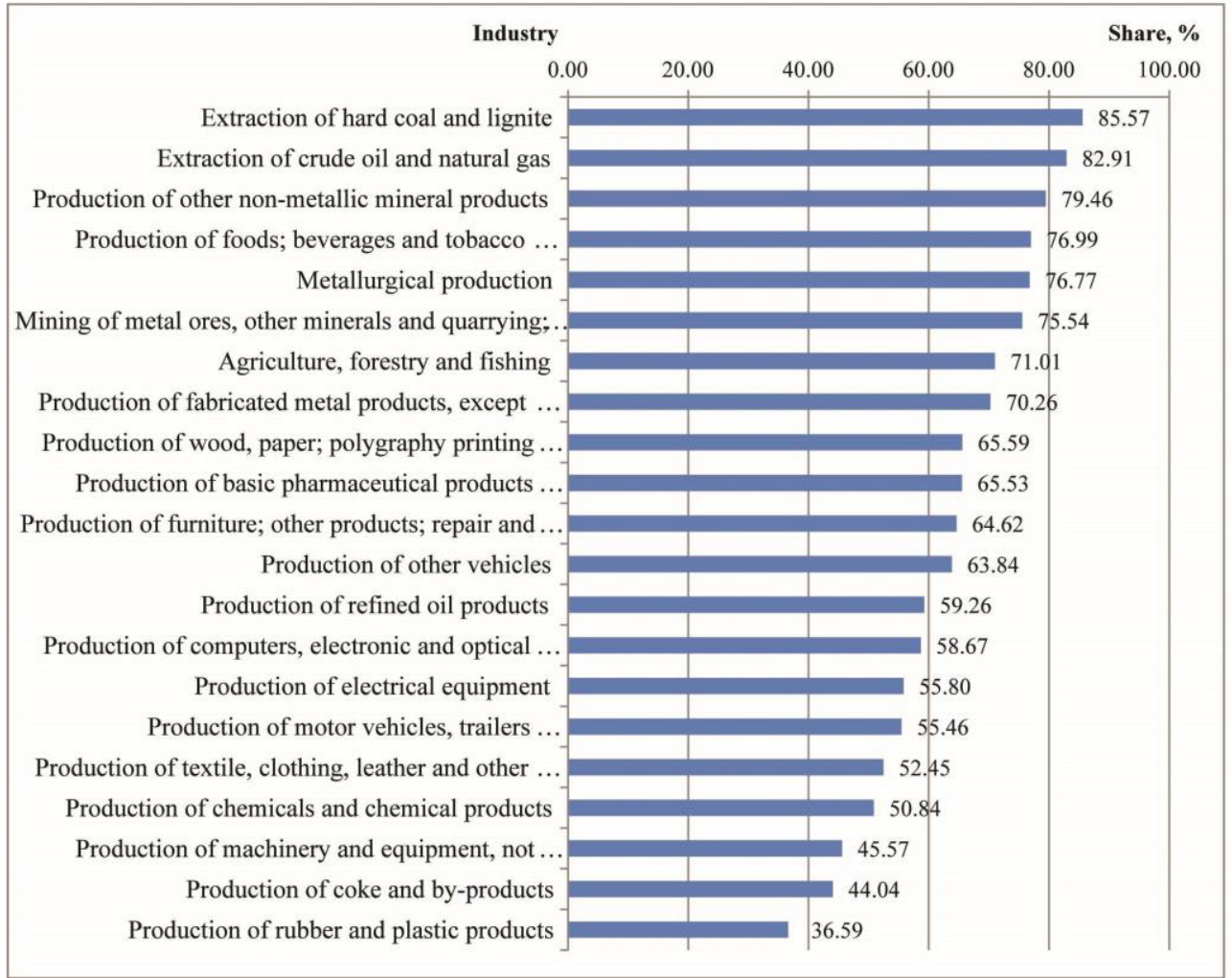

Fig. 3. The rating of individual industries by share of the national added value in their exports Source: computed by the authors based on the data [16].

It is also purposeful to promote the scientific support for the growth of industries with a more significant share in the export structure and a share in the structure of national added export value compared to other sectors of the economy. The computation of the Pearson correlation coefficient between the export structure and the share of national added value in exports of industries has shown a lack of correlation $(-0.03)$, allowing to position industries in the matrix quadrants in the system of coordinates «share in the export structure - share of national added value in exports»».

The matrix of the positioning of industries in the system of coordinates «share in the export structure - share of national added value in exports» in 2018 consists of four quadrants: I - «share in the export structure is below $1.22 \%$ - share of national added value in exports is below $62.21 \%$ »; II - "share in the export structure is above $1.22 \%$ - share of national added value in exports is below $62.21 \%$; III - «share in the export structure is below $1.22 \%$ - share of national added value in exports is above $62.21 \%$; IV - «share in the export structure is above $1.22 \%$ - share of national added value in exports is above $62.21 \% »$. Positioning of Ukrainian industries in the quadrants of the matrix in the system of coordinates «share in the export structure - share of national added value in exports» in 2018 is presented in Table 1.

Based on the carried out positioning of industries in the quadrant IV, which characterizes the shares in the structure of exports and national added value in exports above the average level, the following industries are included - production of foods; beverages and tobacco products; metallurgical production; mining of metal ores, other minerals and quarrying; rendering auxiliary services in mining and quarrying sphere; 
agriculture, forestry and fishing; production of wood, paper; polygraphy printing and duplication.

Table 1. The matrix of the positioning of Ukrainian industries in the quadrants of the system of coordinates «share in the export structure - share of national added value in exports» in 2018

\begin{tabular}{|c|c|c|c|}
\hline \multirow{2}{*}{\multicolumn{2}{|c|}{ Indicator }} & \multicolumn{2}{|c|}{ Share of the national added value in exports, $\%$} \\
\hline & & Below average $1.22 \%$ & Above-average $1.22 \%$ \\
\hline \multirow{2}{*}{ 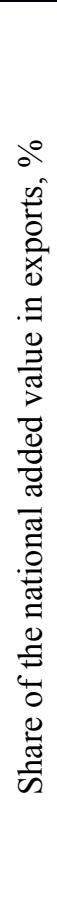 } & 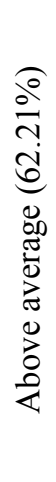 & $\begin{array}{l}\text { Extraction of hard coal and lignite } \\
\text { Extraction of crude oil and natural gas; } \\
\text { Production of other non-metallic mineral } \\
\text { products } \\
\text { Production of fabricated metal products, } \\
\text { except machinery and equipment } \\
\text { Production of essential pharmaceutical } \\
\text { products and preparations } \\
\text { Production of furniture; other products; } \\
\text { repair and installation of machinery and } \\
\text { equipment } \\
\text { Production of other vehicles }\end{array}$ & $\begin{array}{l}\text { Production of foods; beverages, } \\
\text { and tobacco products } \\
\text { Metallurgical production } \\
\text { Mining of metal ores, other } \\
\text { minerals and quarrying; } \\
\text { rendering auxiliary services in } \\
\text { mining and quarrying } \\
\text { Agriculture, forestry and fishing } \\
\text { Production of wood, paper; } \\
\text { polygraphy printing and } \\
\text { duplication }\end{array}$ \\
\hline & 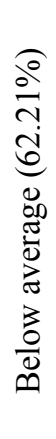 & $\begin{array}{l}\text { Production of textile, clothing, leather } \\
\text { and other materials } \\
\text { Production of computers, electronic and } \\
\text { optical products } \\
\text { Production of electrical equipment } \\
\text { Production of motor vehicles, trailers } \\
\text { and semi-trailers } \\
\text { Production of refined oil products } \\
\text { Production of rubber and plastic } \\
\text { products } \\
\text { Production of coke and by-products }\end{array}$ & $\begin{array}{l}\text { Production of machinery and } \\
\text { equipment, not otherwise } \\
\text { classified } \\
\text { Production of chemicals and } \\
\text { chemical products }\end{array}$ \\
\hline
\end{tabular}

Source: computed by the authors based on the data [16].

Therefore, to ensure the development of the country's economy, it is necessary to pay more attention to those industries that provide a high share in the export structure and have a high share of the national added value in exports.

The next step of the analysis is to compare the national added value in exports of the industries that ensure the growth of exports and national added value in exports with other world countries.

To compare the share of national added value in Ukraine's exports with similar indicators of the world countries, the value-added trading database (TiVA) [17] is used. According to the indicator of national added value in exports (the rating of the world countries is presented by the Fig. 4), Ukraine ranks 19th (83.6\%), which is higher than the average level (73.4\%). 


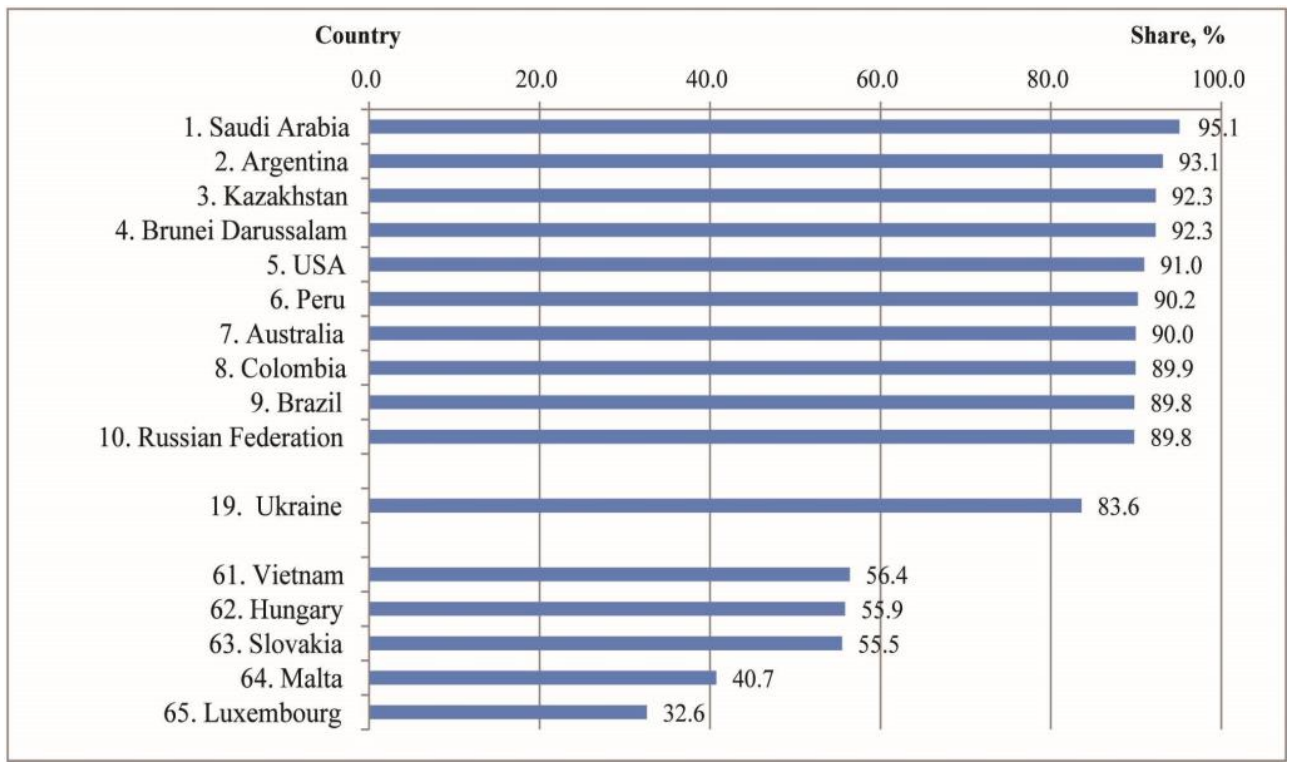

Fig. 4. The share of national added value in exports of the world countries according to the data of the year 2018. Source: computed by the authors based on the data [16, 17].

Studies of the share of national added value in exports of the individual industries of the economy have shown that in the industry of agriculture, forestry, and fisheries, Ukraine ranks 38th among 65 countries of the world (80.8\%), less than the average level of $88.3 \%$ (Fig. 5).

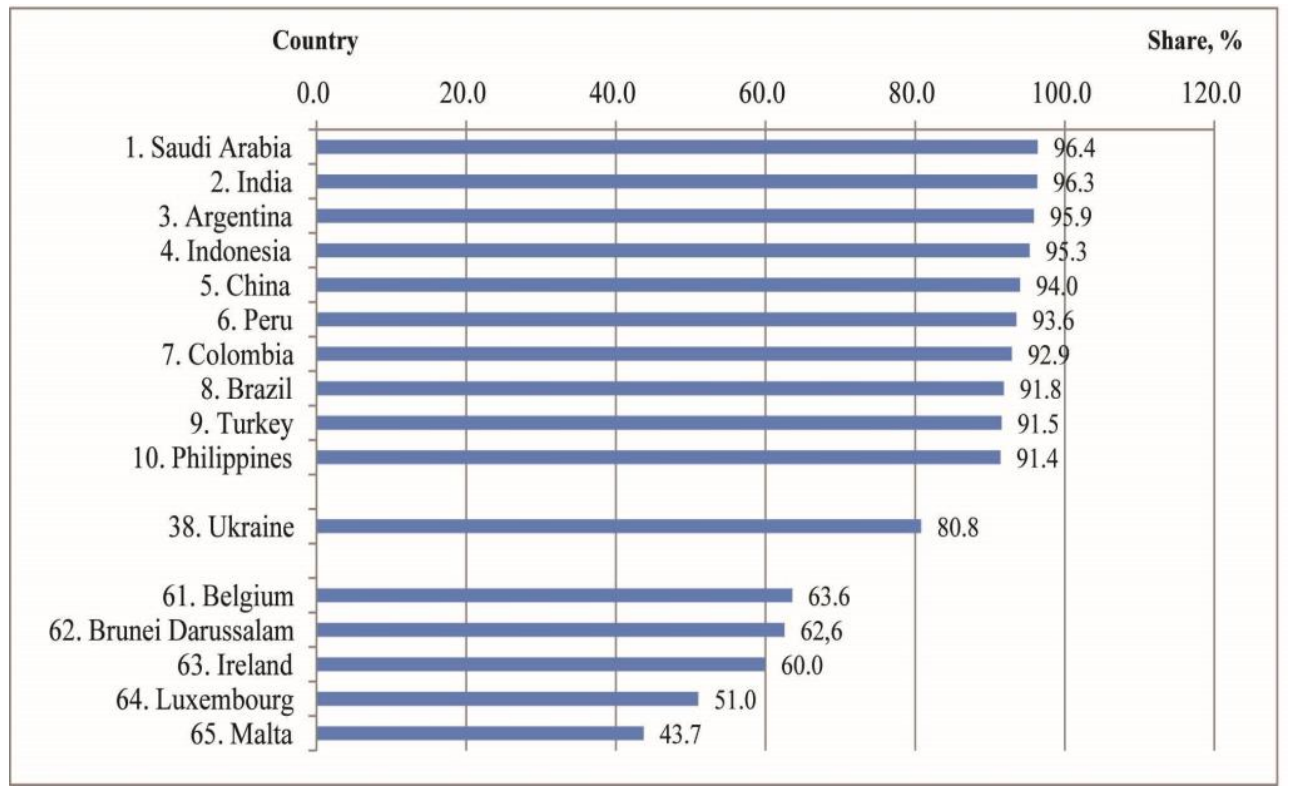

Fig. 5. The share of the national value-added in exports of the world countries in agriculture, forestry and fisheries in 2018. Source: computed by the authors based on the data $[16,17]$.

In mining non-energy products, Ukraine ranks 20 th out of 65 countries $(86.5 \%)$, i.e., above the average level of $73.4 \%$ (Fig. 6). 


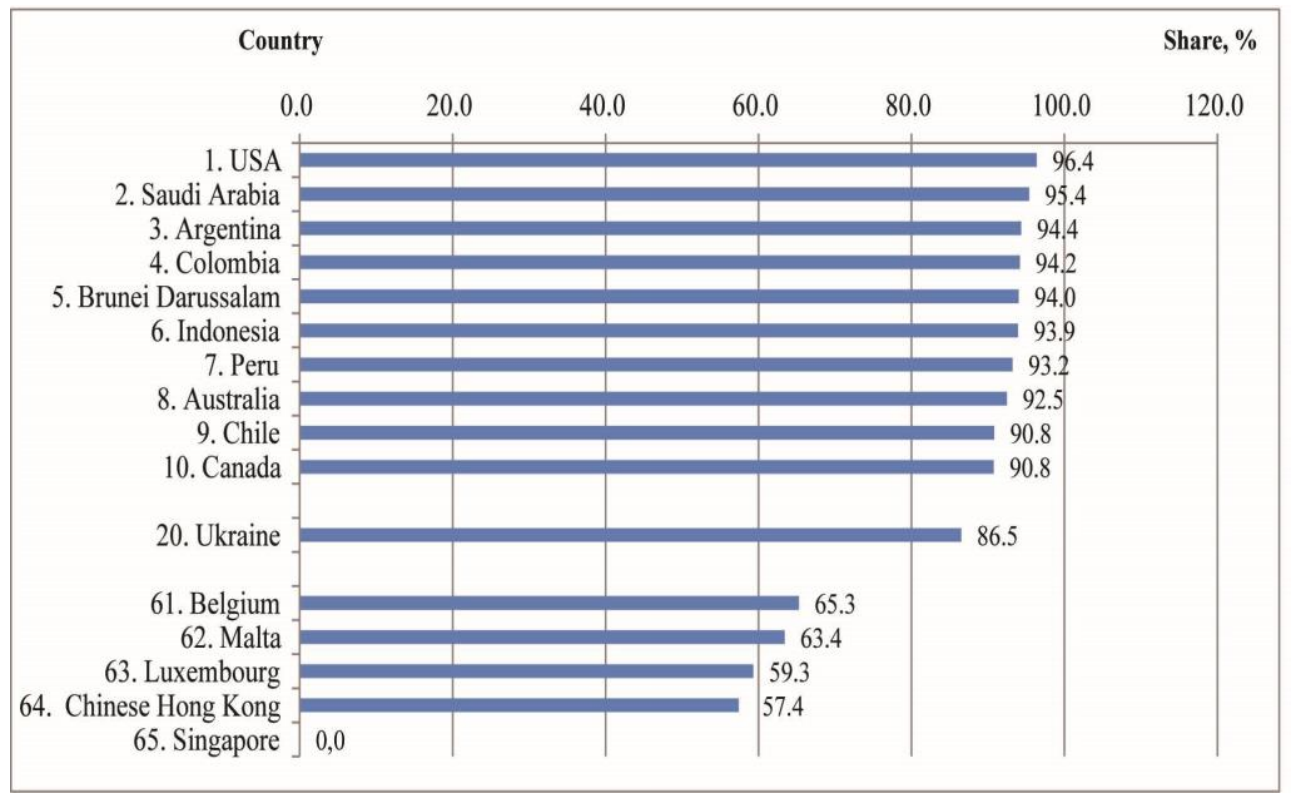

Fig. 6. The share of national added value in exports of the world countries in mining non-energy products in 2018. Source: computed by the authors based on the data $[16,17]$.

In the industry of production of foods, beverages and tobacco, Ukraine ranks 22nd out of 65 countries $(81.5 \%$ ), which is also above the average level of $76.9 \%$ (Fig. 7).

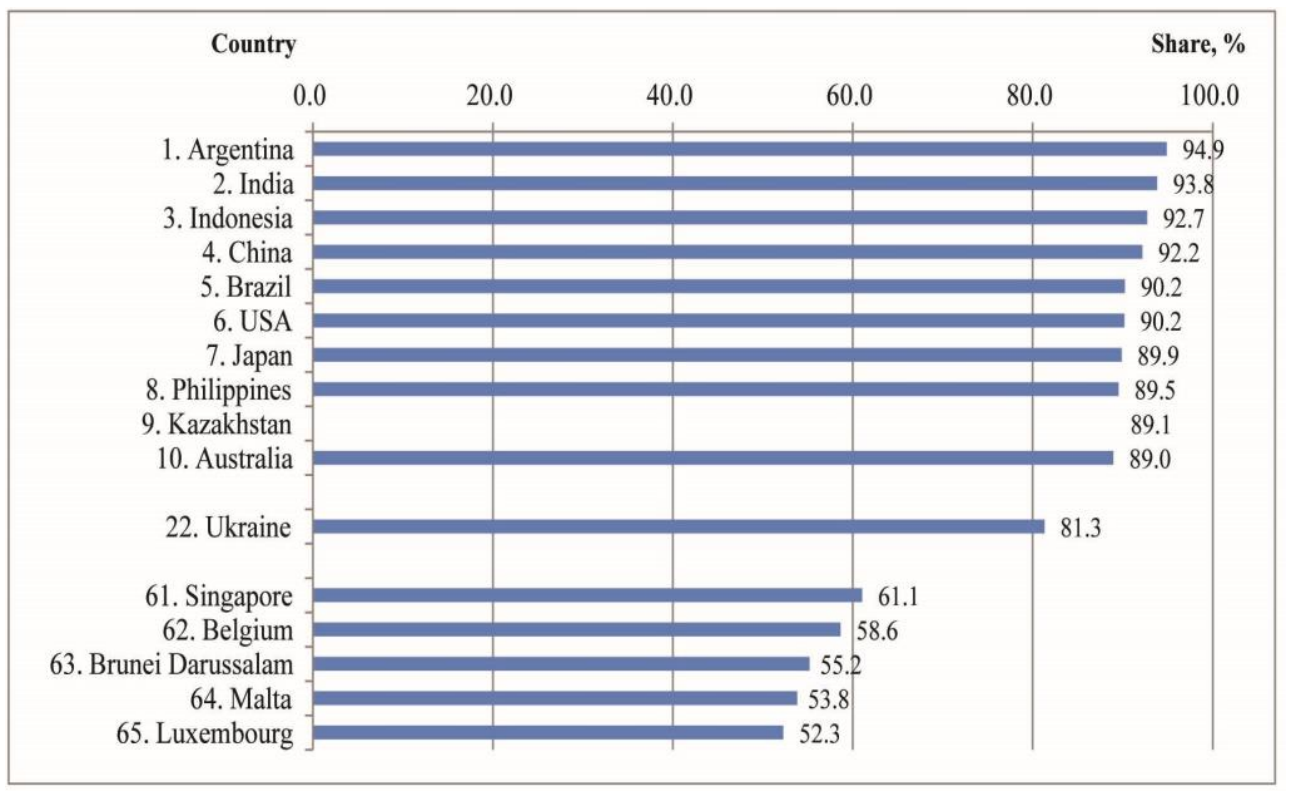

Fig. 7. The share of national added value in exports of the world countries in the production of foods, beverages and tobacco in 2018. Source: computed by the authors based on the data $[16,17]$.

In the production of chemical and pharmaceutical products, Ukraine ranks 45 th out of 65 countries $(65.2 \%)$, below the average level of $77.6 \%$ (Fig. 8). 


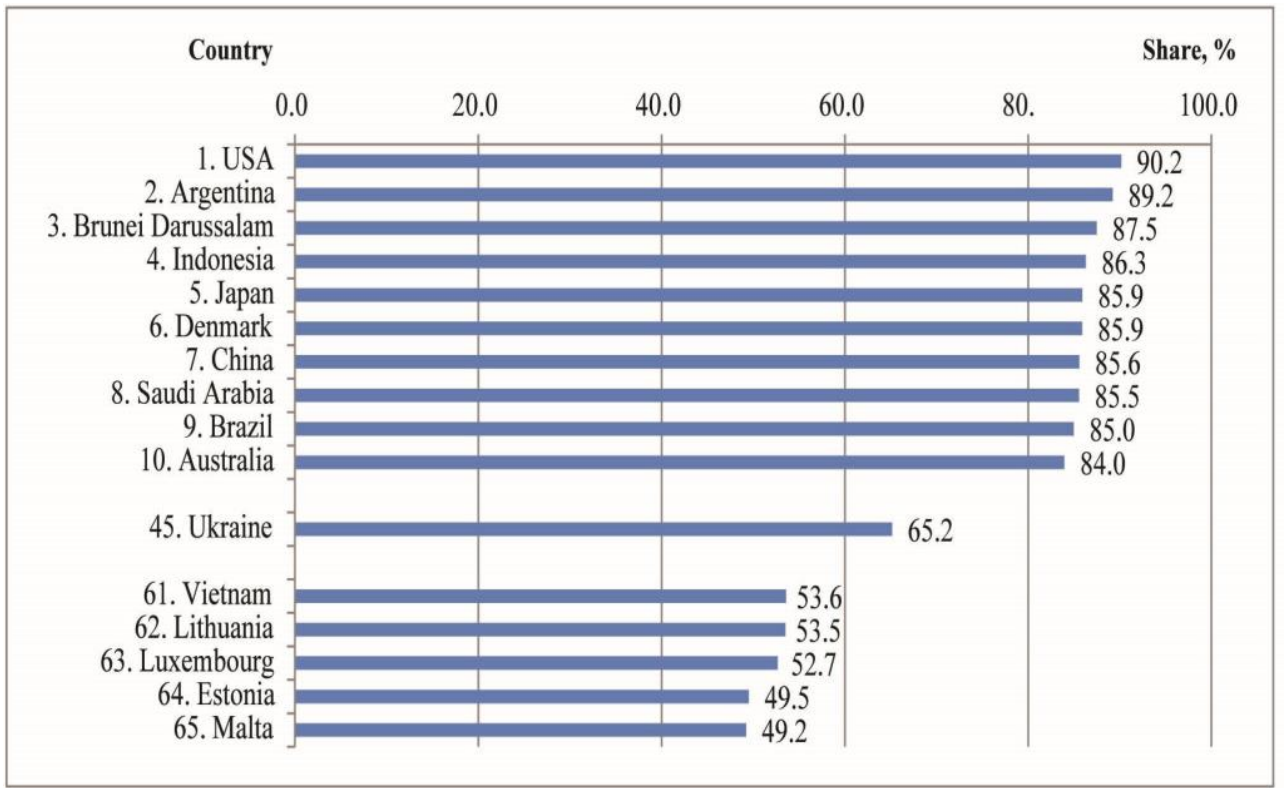

Fig. 8. The share of national added value in exports of the world countries in chemical and pharmaceutical products in 2018. Source: computed by the authors based on the data [16, 17]

In the industry of metallurgical production, Ukraine ranks 45 th out of 65 countries (65.2\%), i. e., below the average level of $77.6 \%$ (Fig. 9).

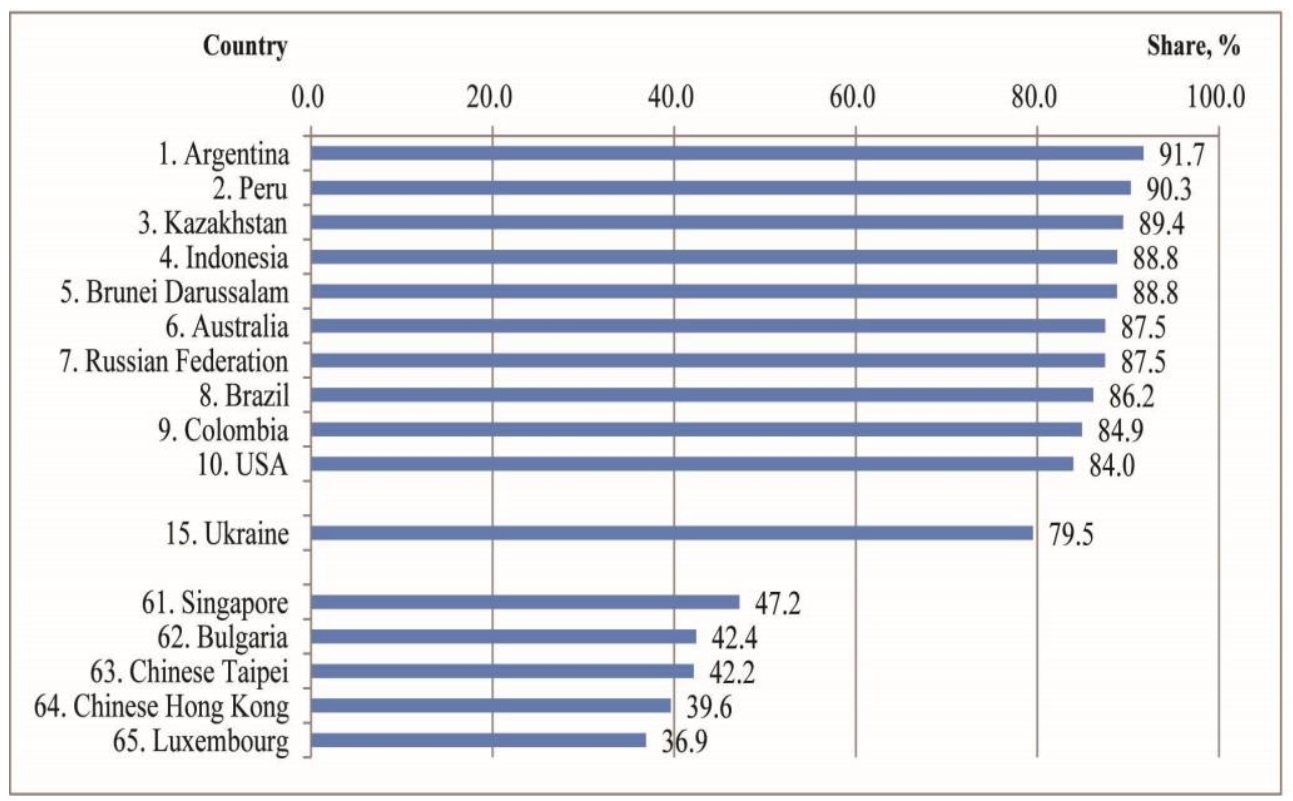

Fig. 9. The share of national added value in exports of world countries in the industry of metallurgical production in 2018. Source: computed by the authors based on the data [16, 17].

In the computer, electronic and optical production industry, Ukraine ranks 34th out of 65 countries $(70.2 \%)$, which is below the average level of $71.7 \%$ (Fig. 10). 


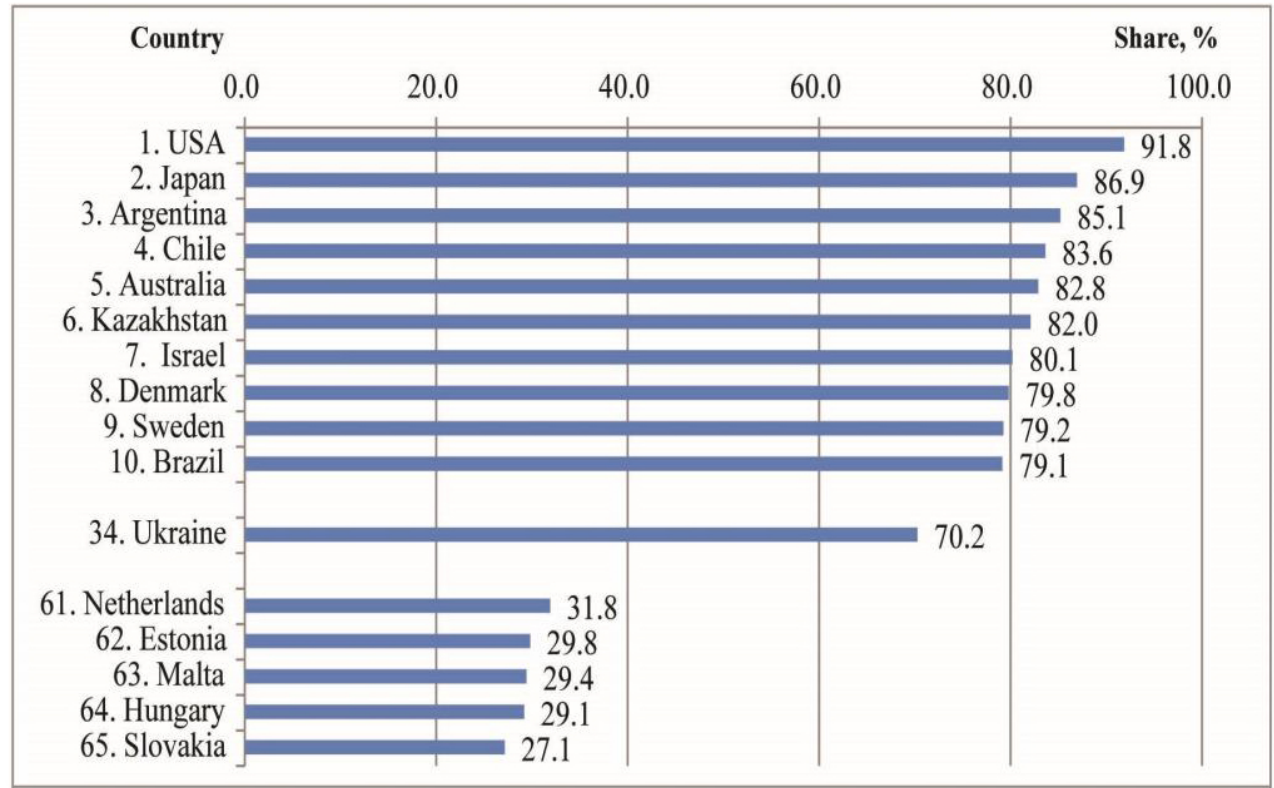

Fig.10. The share of national added value in exports of world countries in computer, electronic and optical production in 2018. Source: computed by the authors based on the data [16, 17].

In the industry of electrical equipment production, Ukraine ranks 33rd out of 65 countries $(64.6 \%)$, which is below the average level of $66.8 \%$ (Fig. 11).

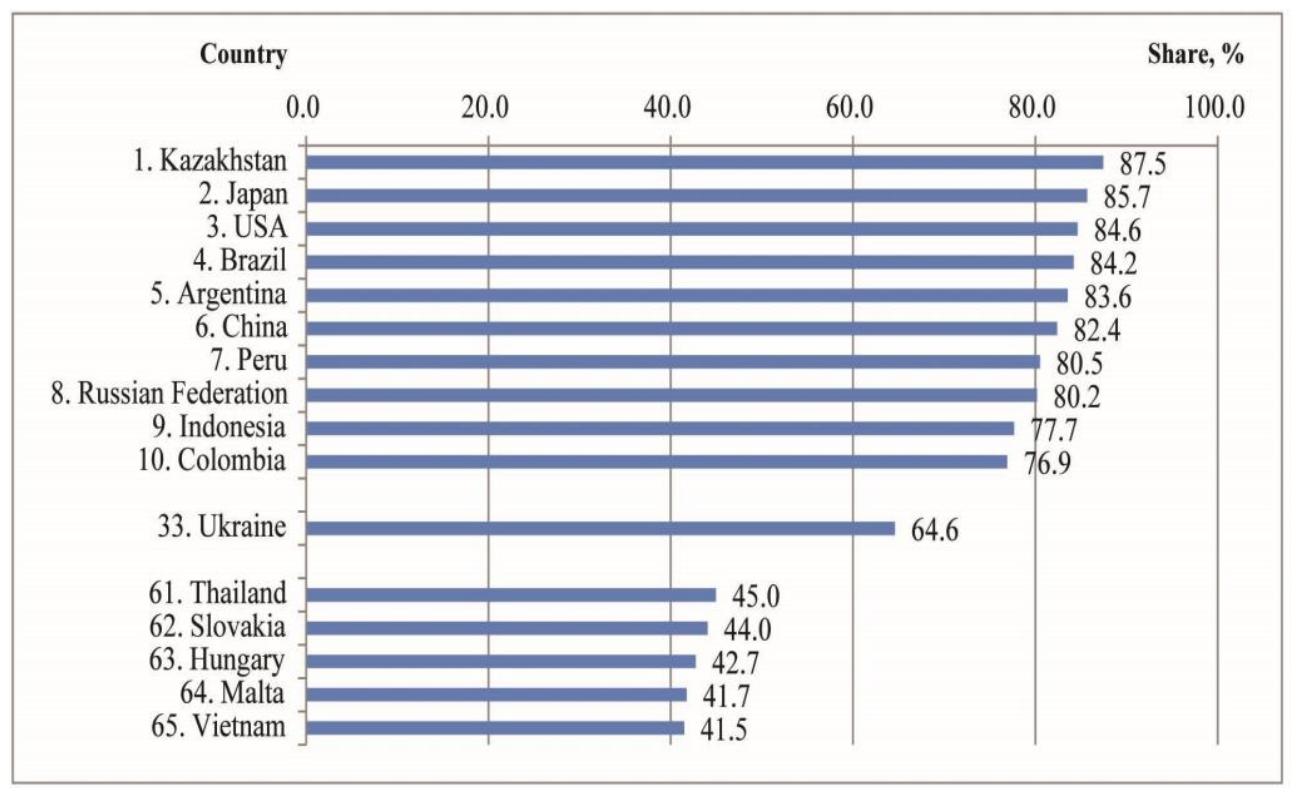

Fig. 11. The share of national added value in exports of world countries in the production industry of electrical equipment in 2018. Source: computed by the authors based on the data [16, 17].

In the machinery and equipment production industry, Ukraine ranks 49th out of 65 countries $(61.8 \%)$, below the average level of $76.9 \%$ (Fig. 12). 


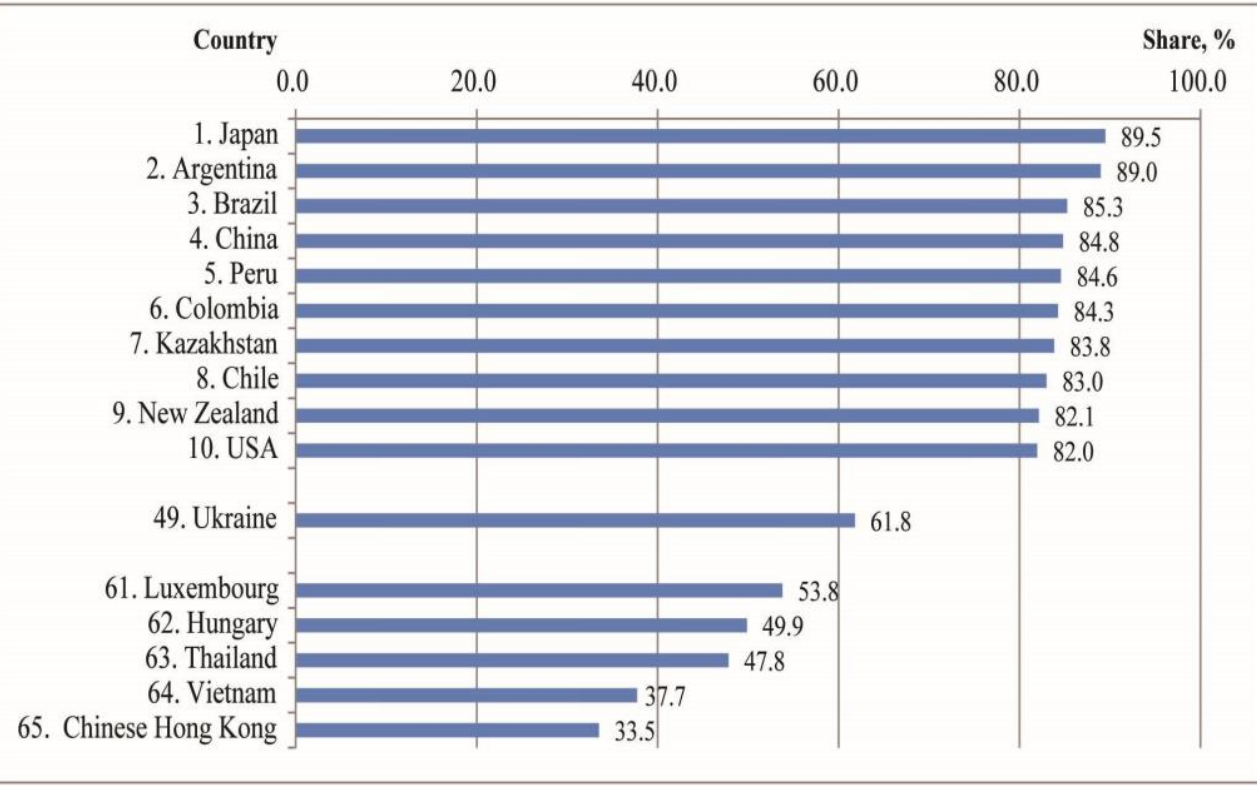

Fig. 12. The share of national added value in exports of world countries in the industry of machinery and equipment production in 2018. Source: computed by the authors based on the data $[16,17]$.

Ergo, the carried out analysis of the share of national added value in the exports of Ukraine allows us to conclude that this indicator is generally higher for the mining industries than other world countries. In comparison, this indicator is lower for the manufacturing industries, which justifies the domestic industry's dependence on imported components based on foreign technologies. There are virtually no knowledge-intensive and innovative stages of production of machine-building products in Ukraine. Technological lag and reduction of industrial production, which has been observed for a long time in the country's economy, have caused the decline of national high-tech industries [18]. This state and tendencies in the development of domestic industries have led to the deepening of Ukraine's specialization in the exports of products with low-level processing.

The need to reduce the impact of risks in terms of foreign economic security and attract foreign investments for the industrialization of the Ukrainian economy can be achieved by increasing the concentration of knowledge-intensive and innovative stages of production in the industry.

Given the world experience, the main directions of the State policy on intensification of the involvement of Ukrainian producers in global value chains can be formulated as follows:

- need's identification to increase the concentration of knowledge-intensive and innovative stages of production in the industry as crucial support for economic development at the level of the economic strategy of the State;

- use of development institutions to ensure the necessary conditions for the integration of Ukrainian enterprises into global value chains (national financial development institutions have the most significant potential of the State support in the studied aspect);

- the State support for exports, which, in addition to the State-based programming and institutional provision, should also include improvement of the regulatory environment; formation of innovative market infrastructure with the transfer of innovations; accumulation of funds for the scientific researches necessary for exporters; support of the financial leasing and franchising; training personnel in the field of international trade; reducing the tax pressure; ensuring the partnership between local authorities and 
entrepreneurial associations; participation of local authorities in the regional and interregional trade associations; spread of information about the export and investment opportunities of enterprises in the region; provision of consulting services, etc.;

- special economic regimes of a territorial nature, which causes the use of the compact location of high-tech productions in the context of the inclusion of their products in global value chains;

- subsystem of the tax policy instruments, including special economic zones and tax regimes with the industry orientation, the local (elemental) tax benefits.

The defined vital directions of the State support are interrelated and interdependent, should be used simultaneously and are being considered as subsystems that comprise a system of State support for involving Ukrainian producers in global value chains.

\section{Conclusions and Discussion}

Thus, as a result of the carried out study, we can specify the following:

1. In modern conditions of the deepened globalization processes, the role of determination of the volume of exports of products with high added value, as well as their enclosing in global value chains, is increasing

2. The methodical approach to assessing the enclosing of Ukrainian industries in global value chains is proposed, which allows determination of the state of involvement of the country in the international division of labour.

3. The most significant shares in the export structure of Ukraine's industry in 2018 belong to metallurgical production (18.27\%), agriculture, forestry and fisheries $(16.72 \%)$, food and beverage production (14.96\%). At the same time, high-tech industries in Ukraine have a small share in the export structure.

4. The study of the share of exports in the production of individual industries has shown that the most significant shares of exports in production output belong to metallurgical production (63.57\%), production of electrical equipment $(60.45 \%)$, machinery and equipment production $(59.65 \%)$.

5. The following industries demonstrate a high share of the national added value in exports: black and brown coal mining $(85.57 \%)$, crude oil and natural gas production $(82.91 \%)$, production of foods; beverages and tobacco products $(76.99 \%)$, metallurgical production $(76.77 \%)$, metal ore mining, other minerals and quarrying $(75.54 \%)$, agriculture, forestry and fisheries $(71.01 \%)$ - mining industry mainly.

6. The carried out positioning of industries in the system of coordinates «share in the export structure - share of national added value in exports» allowed to allocate the industry sectors of the economy that have shares in the structure of exports and national added value of exports above the average level, with a high impact on the economic activity of Ukraine as an exporting country.

7. The study of the share of national added value in Ukrainian exports compared to other world countries has shown that in the mining industry, this indicator is higher. In contrast, in the manufacturing industries, the average level is lower, justifying the dependence of the domestic industry on imported components based on foreign technologies. In Ukraine, there are virtually no knowledge-intensive and innovative stages of production of machine-building products, which has led to the deepening of Ukraine's specialization in the export of low-processed products.

8. The directions of the State policy on intensification of involvement of Ukrainian producers in global value chains are proposed and should function simultaneously for their more significant effect, including identification of the need to increase the concentration of knowledge-intensive and innovative stages of production in the industry at the level of the economic strategy of the State; use of development institutions; the State support for 
exports; special economic regimes of a territorial nature; subsystem of the tax policy instruments.

\section{References}

1. V. Khaustova, O. Reshetnyak, R. Lobodin, Evaluating the Impact of the Scientific Activity of a Country on the Provision of its Economic Security, 36th IBIMA Conference: 4-5 November, Granada, Spain (2020). URL: https://ibima.org/acceptedpaper/evaluating-the-impact-of-the-scientific-activity-of-a-country-on-the-provisionof-its-economic-securi

2. M. Kyzym, O. Reshetnyak, O. Kozyrieva, V. Khaustova, Research Organization on The Basis of The World Foresights Analysis: Trends and Scenarios, 35th IBIMA Conference: 1-2 April, Seville, Spain. (2020). URL: https://ibima.org/acceptedpaper/research-organization-on-the-basis-of-the-world-foresights-analysis-trends-andscenarios

3. D. Hummels, J. Ishii, K-M. Yi, Journal of International Economics, 54, Iss. 1, 75-96 (2001) DOI: https://doi.org/10.1016/S0022-1996(00)00093-3

4. R. Koopman, Z. Wang, Sh-J Wei, How Much of Chinese Exports Is Really Made in China? Assessing Foreign and Domestic Value-Added in Gross Exports, Office of Economics Working Paper, U. S. International Trade Commission, 2008-03-B. (2008) DOI: $10.3386 /$ w14109.

5. R. Jonson. Five, Journal of Economic Perspectives, 28, 119-142 (2014) DOI: 10.1257/jep.28.2.119.

6. X. Chen., et al. The Estimation of Domestic Value-Added and Employment Induced by Exports: An Application to Chinese Exports to the United States. In China and Asia: Economic and financial interactions. Oxon: Routledge, 64-82 (2009)

7. Global Value Chains and Development: Investment and Value Added Trade in the Global Economy: A preliminary analysis. UNCTAD, DIAE, 40 (2013) URL: https://unctad.org/system/files/official-document/diae2013d1_en.pdf

8. M. Kyzym, V. Khaustova, V. Shlykova, H. Kramarev, A. Pinchuk, The Problems of Economy, 4, 19-29 (2018) DOI: https://doi.org/10.32983/2222-0712-2018-4-19-29

9. I.Gryshova, M. Kyzym, V. Khaustova, V. Korneev, H.Kramarev, Sustainability, 12, 2072 (2020)DOI:10.3390/su12052072

10. I. Gryshova, M. Kyzym, I. Hubarieva, V. Khaustova, A. Livinskyi, M. Koroshenko, Sustainability, 12, 7692 (2020) DOI:10.3390/su12187692

11. V. Krivorotov, V. Mokhov, O. Ivanova, O. Polyakova, Convergence modelling in international integration associations, Bulletin of the South Ural State University. Ser. Mathematical Modelling, Programming \& Computer Software (Bulletin SUSU MMCS). 13, 68-72 (2020) DOI: 10.14529/mmp200306

12. A. Bykov, O. Kolb, Belarusian Economic Journal, 1, 128-143 (2016) URL: http://edoc.bseu.by:8080/bitstream/edoc/30257/1/Bykov_A._A.._s._128_143.pdf

13. A. Bykov et al., Scientific works of the Belarusian State Economic University, 12, 6372 (2019) URL: https://ndc-ipr.org/media/publications/files/Bykov_A.A._s_63_72.pdf

14. I. Tochitskaya, Assessment of value added in the export of Belarus, Bankay̆ski Vesnik. KRASAVIK, 3-11 (2020) URL: http://www.nbrb.by/bv/articles/10746.pdf

15. Guide to OECD's Trade in Value Added (TiVA) Indicators. OECD (2019) URL: https://www.oecd.org/sti/ind/tiva/TiVA2018_Indicators_Guide.pdf

16. Tables "input-output" (in consumer prices) for 2013-2018 / Official site of the State Statistics Service of Ukraine. URL:

http://ukrstat.gov.ua/operativ/operativ2006/vvp/vitr_vip/vitr_u/arh_vitr_u.html 
17. Trade in Value Added (TiVA): Principal indicators. OECD. Stat. URL: https://stats.oecd.org/Index.aspx?DataSetCode=TIVA_2018_C1

18. O. Reshetnyak, Economy and State, 9, 44-51 (2020) DOI: 10.32702/23066806.2020.9.44 